ARTICLE

Received 11 Nov 2012 | Accepted 5 Mar 2013 | Published 16 Apr $2013 \quad$ DOl: 10.1038/ncomms2702

\title{
Louisville seamount subduction and its implication on mantle flow beneath the central Tonga-Kermadec arc
}

\author{
Christian Timm ${ }^{1}$, Daniel Bassett ${ }^{2}$, lan J. Graham ${ }^{1}$, Matthew I. Leybourne ${ }^{1, \dagger}$, Cornel E.J. de Ronde ${ }^{1}$ \\ Jon Woodhead ${ }^{3}$, Daniel Layton-Matthews ${ }^{4} \&$ Anthony B. Watts ${ }^{2}$
}

Subduction of intraplate seamounts beneath a geochemically depleted mantle wedge provides a seldom opportunity to trace element recycling and mantle flow in subduction zones. Here we present trace element and $\mathrm{Sr}, \mathrm{Nd}$ and $\mathrm{Pb}$ isotopic compositions of lavas from the central Tonga-Kermadec arc, west of the contemporary Louisville-Tonga trench intersection, to provide new insights into the effects of Louisville seamount subduction. Elevated ${ }^{206} \mathrm{~Pb} /$ ${ }^{204} \mathrm{~Pb},{ }^{208} \mathrm{~Pb} /{ }^{204} \mathrm{~Pb},{ }^{86} \mathrm{Sr} /{ }^{87} \mathrm{Sr}$ in lavas from the central Tonga-Kermadec arc front are consistent with localized input of subducted alkaline Louisville material (lavas and volcaniclastics) into sub-arc partial melts. Furthermore, absolute Pacific Plate motion models indicate an anticlockwise rotation in the subducted Louisville seamount chain that, combined with estimates of the timing of fluid release from the subducting slab, suggests primarily trench-normal mantle flow beneath the central Tonga-Kermadec arc system.

\footnotetext{
${ }^{1}$ Department of Marine Geoscience, GNS Science, PO Box 30-368, Lower Hutt 5040, New Zealand. ${ }^{2}$ Department of Earth Sciences, University of Oxford Oxford OX1 3AN, UK. ${ }^{3}$ School of Earth Sciences, University of Melbourne, Melbourne, Victoria 3010, Australia. ${ }^{4}$ Department of Geological Sciences and Geological Engineering, Queen's University, Kingston, Ontario, Canada K7L 3N6. † Present address: ALS Geochemistry, 2103 Dollarton Hwy, North Vancouver, British Columbia, Canada. Correspondence and requests for materials should be addressed to C.T. (email: c.timm@gns.cri.nz).
} 
S ites of plate convergence (subduction zones) have a key role in material recycling on Earth. A volcanic arc is the surface expression of subduction-accompanied dehydration and partial melting processes at depth. During dehydration at higher pressures, hydrous fluids are expelled from the subducting slab (consisting of sediment cover, altered oceanic crust and serpentenized uppermost lithosphere) into the overlying mantle wedge. This lowers the mantle solidus, resulting in partial melting. Arc lavas commonly carry signals of these fluids, which could be either aqueous fluids or supercritical fluids and melts (for example, refs 1-3). There is some consensus among researchers concerning the transfer of elements via fluids from the subducting slab and partial melting of the overlying mantle wedge, but there is debate regarding the geometry of mantle flow in the wedge. Classical mantle corner flow models invoke trenchnormal flow geometry in the mantle wedge, a hypothesis supported by seismic anisotropies observed in the Izu Bonin $\operatorname{arc}^{4}$. Conversely, trench-parallel mantle flow has been suggested beneath the Central American Arc ${ }^{5}$ and Vanuatu Arc ${ }^{6}$, based on both seismic anisotropy measurements and arc geochemical signatures. Trench-parallel seismic anisotropies identified along the northern Tonga $\operatorname{arc}^{7,8}$ have been interpreted as reflecting rapid, along-arc southward mantle flow, consistent with the inflow of Indo-Australian mantle replacing Pacific mantle along the northern Lau Basin ${ }^{9}$. Since $\sim 4 \mathrm{Ma}$, the Louisville seamount chain on the Pacific Plate is believed to have undergone subduction beneath the Indo-Australian plate. Assuming a consistency in azimuth between the unsubducted and subducted portion of the Louisville seamount chain, the obliquity between the unsubducted chain azimuth and the convergence azimuth suggests a net southward migration of the collision zone ${ }^{10}$. Geochemical data from the Tonga and northern Kermadec arc show a depleted MORB-type mantle wedge composition (for example, refs 11,12). This composition should be highly sensitive to contamination by enriched components, such as alkaline Louisville seamount material (for example, refs 13-15), making this an ideal region in which to study material recycling from the subducting slab, and mantle wedge flow geometry.

Here, we present evidence for the existence of a radiogenic isotope signature derived from subducting Louisville seamount chain rocks in recent lavas $(<10 \mathrm{ka})$ from the central TongaKermadec arc volcanic centers ' $U$ ', ' $V$ ' and Monowai, and the southern Lau back arc and older lavas $(<100 \mathrm{ka})$ from Ata Island (hereafter collectively named central Tonga-Kermadec arc). All of these sites are located near the contemporary point of collision between the Louisville seamount chain and the Tonga-Kermadec trench. Geochemical evidence is complemented by analyses of seismicity and forearc morphology, which in addition to plate reconstruction models support previous suggestions ${ }^{16}$ of an alternate more westerly geometry for the subducted portion of the Louisville seamount chain.

\section{Results}

Geological and geochemical background. Located in the southwest Pacific ocean, the $\sim 2,600$-km-long Tonga-Kermadec arc is the most linear, fastest converging and most seismically active subduction boundary on Earth (for example, ref. 17; Fig. 1). This collision zone between the Pacific and Indo-Australian tectonic plates is characterized by one of the world's deepest trenches and the most volcanically active arc, with the highest density of submarine volcanic centers $(>1 \text { per } 50 \mathrm{~km} \text { of strike })^{18}$. At $\sim 25.4^{\circ} \mathrm{S}$ the Tonga-Kermadec trench is intersected by the Louisville Ridge, a $\sim 4,300$-km-long chain of seamounts and guyots, which formed over the past $80 \mathrm{Myr}$ as the Pacific Plate

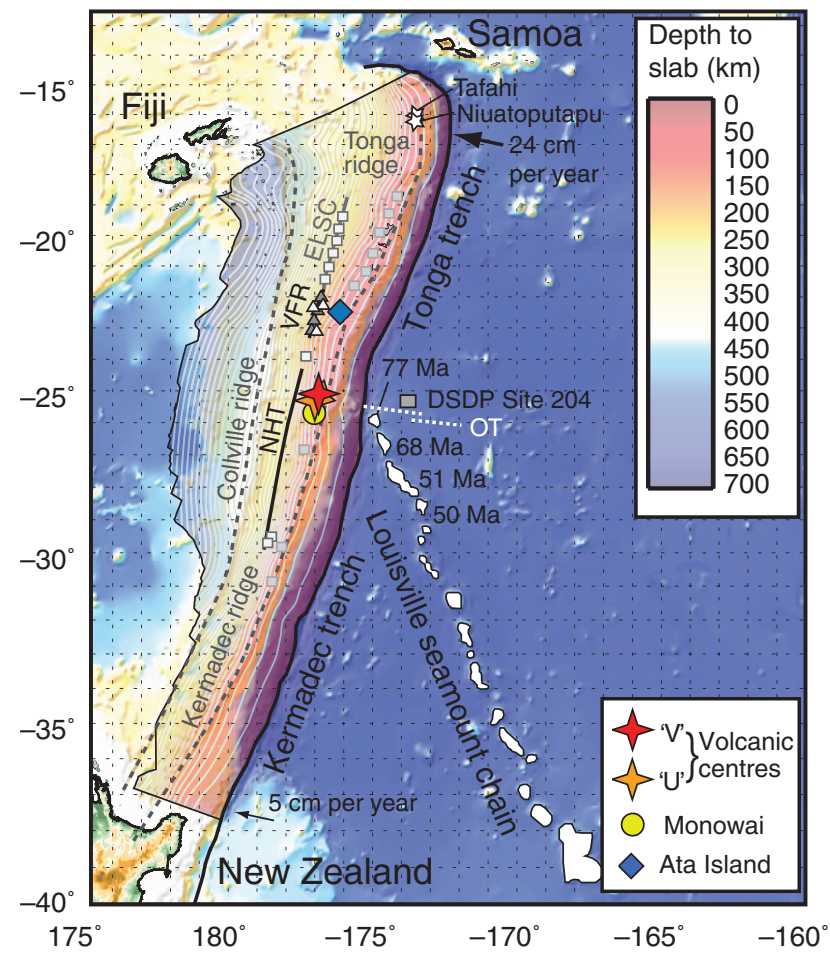

Figure 1 | Bathymetric map of the Tonga-Kermadec arc system.

Map showing the depth of the subducted slab beneath the TongaKermadec arc system (modified after USGS slab surface figure; http:// earthquake.usgs.gov/research/data/slab). Louisville seamount ages are after Koppers et al. ${ }^{49}$ ELSC, eastern Lau-spreading centre; DSDP, Deep Sea Drilling Programme; NHT, Northern Havre Trough; OT, Osbourn Trough; VFR, Valu Fa Ridge. Arrows mark total convergence rates ${ }^{17}$. Grey squares (named volcanic centers), white squares (Lau Basin, Havre Tough) and grey and white triangles (Valu Fa ridge and seamounts) mark sample locations.

passed over a hotspot presently located near the intersection of the Eltanin Fracture Zone and the East Pacific Rise ${ }^{19}$. This collision zone is coincident with the first-order tectonic boundary between the Tonga and Kermadec segments of the plate boundary, which exhibit significant differences in forearc morphology, subducting slab geometry, back-arc-spreading dynamics and seismicity ${ }^{20-22}$.

The Pacific plate increases in age from $\sim 85$ to $144 \mathrm{Ma}$ north and south of the Osbourn trough paleo-spreading centre, respectively ${ }^{23,24}$, which, together with a $\sim 200$-m-thick sediment cover (drilled at DSDP Site 204 west of the trench, see Fig. 1), has been subducting beneath the Australian Plate since at least the late Oligocene (for example, ref. 25). The volcanic front in this region lies between $\sim 140 \mathrm{~km}$ (Monowai) and $\sim 190 \mathrm{~km}$ (Ata) west of the trench, $40-60 \mathrm{~km}$ west of the Kermadec Ridge (for example, refs 26,27) and 120-130 km above the subducting slab (average slab dip of $\sim 30^{\circ}$, which steepens to $\sim 45^{\circ}$ beneath a depth of $120 \mathrm{~km}$; Fig. 1$)^{28}$.

The volcanic centers ' $U$ ' $\left(25.44^{\circ} \mathrm{S} ; 177.11^{\circ} \mathrm{W}\right)$ and ' $\mathrm{V}$ ' $\left(25.19^{\circ} \mathrm{S}\right.$; $\left.177.06^{\circ} \mathrm{W}\right)^{29}$ are located $\sim 320 \mathrm{~km}$ south of Ata, $\sim 180 \mathrm{~km}$ west of the current intersection between the Tonga-Kermadec trench and the Louisville seamount chain, and $\sim 50 \mathrm{~km}$ north of the atypically large mafic Monowai volcanic centre. Both were sampled during the R/V Tangaroa NZAPLUME III expedition in 2004.

Sixteen $100 \%$ normalized volatile-free rock compositions from ' $U$ ' (8) and 'V' (8) range from basalt to rhyolite (49.6-71.3 wt.\% 


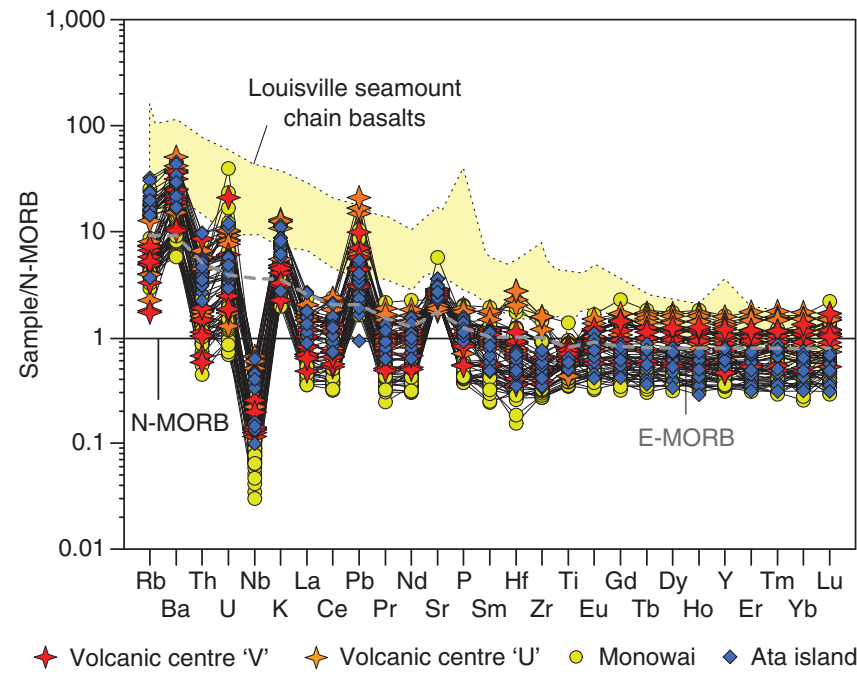

Figure 2 | Multi-element diagram. N-MORB normalized ${ }^{31}$ multi-element $^{2}$ diagram of the volcanic centers Monowai ${ }^{12}, \mathrm{U}, \mathrm{V}$ (this study) and $\mathrm{Ata}^{26}$. Yellow field represents the Louisville seamount chain lavas (LSCL) after refs 13-15. Grey dashed line marks average enriched mid-ocean ridge basalts (E-MORB) after Sun and McDonough ${ }^{31}$.

$\left.\mathrm{SiO}_{2}\right)^{27}$ and belong to the low- $\mathrm{K}$ tholeiitic series ${ }^{30}$. All the lavas show typical arc-type enrichments of large ion lithophile elements (LILE; Rb, Ba, U, K, Pb, Sr), Nb depletions compared with normal mid-ocean ridge basalt (N-MORB after Sun and $\mathrm{McDonough}^{31}$ ) and depleted- to slightly enriched-MORB-type high-field element distributions on a multi-element diagram (Fig. 2, Supplementary Table S1). Sr and Pb isotopic compositions of lavas from ' $U$ ', ' $V$ ', Monowai and Ata are generally more radiogenic than Pacific and Indian MORB (Fig. 3) ${ }^{12,32,33}$, but their Nd isotopic compositions fall within the MORB range ${ }^{34}$. The $\mathrm{Sr}, \mathrm{Nd}$ and ${ }^{207} \mathrm{~Pb} /{ }^{204} \mathrm{~Pb}$ isotopic values are similar, but the ${ }^{206} \mathrm{~Pb} /{ }^{204} \mathrm{~Pb}$ and ${ }^{208} \mathrm{~Pb} /{ }^{204} \mathrm{~Pb}$ values are more radiogenic than most other lavas sampled along the mid-Tonga to northern Kermadec arc segments. Similarly high ${ }^{206} \mathrm{~Pb} /{ }^{204} \mathrm{~Pb}$ and ${ }^{208} \mathrm{~Pb} /{ }^{204} \mathrm{~Pb}$ values are apparent in back-arc lavas from the southern Valu Fa Ridge and in seamounts east of Ata Island and the southern Lau Basin at $23.93^{\circ} \mathrm{S}$ (Fig. 3) ${ }^{32,35-38}$.

Central Tonga-Kermadec arc and back-arc geochemical variations. Elevated contents of aqueous fluid-mobile elements (for example, $\mathrm{Ba}, \mathrm{Sr}, \mathrm{Pb}, \mathrm{U}$ ) and generally MORB-like contents and ratios of aqueous fluid-immobile elements (for example, $(\mathrm{La} / \mathrm{Sm})_{\mathrm{N}}<0.9 ; N=$ normalized to $\mathrm{C} 1$ chondrite after McDonough and $\left.\operatorname{Sun}^{39}\right)^{12,32}$ in Monowai, ' $U$ ' and ' $V$ ' lavas are consistent with element transfer from the subducting slab to the central Tonga-Kermadec mantle wedge via aqueous fluids ${ }^{2}$.

Lavas from Ata, however, have elevated $(\mathrm{La} / \mathrm{Sm})_{N} \geq 0.9$, indicating either a lower degree of partial melting, or a local source enrichment in the mantle wedge ${ }^{26}$. Back-arc lavas show similar elevations in $(\mathrm{La} / \mathrm{Sm})_{N}$, which increases from $\sim 0.6$ at the eastern Lau-spreading centre, to $\geq 1.0$ at the southern tip of the Valu Fa ridge (for example, refs 33,35-37). This increase has been attributed to the north-south reduction in distance between the Valu $\mathrm{Fa}$ ridge and the arc front volcanoes, which reaches a minimum of $\sim 40 \mathrm{~km}$ between the arc front and the southern tip of the Valu Fa Ridge ${ }^{35}$, and whose melts therefore may have influenced the melt genesis in the back-arc mantle (for example, ref. 33). A single analysis from the southernmost Lau Basin sampled at $23.9^{\circ} \mathrm{S}^{32}$, however, shows relatively low $(\mathrm{La} / \mathrm{Sm})_{N}$ of $\sim 0.6$, also suggesting that local source enrichment beneath the Ata region has taken place.
There are two primary explanations for the $\mathrm{Sr}$ and $\mathrm{Pb}$ isotope variability in arc lavas: (1) mantle wedge compositional heterogeneity, and (2) variable incorporation of subducted material (that is, sediment cover, altered oceanic crust and serpentenized, uppermost lithosphere) into partial melts. Although it has been proposed that the $\mathrm{Nd}$ and $\mathrm{Hf}$ isotopic compositions of northern Tonga-southern Kermadec lavas represent pre-existing mantle wedge heterogeneities (for example, refs 12,40,41), the corresponding $\mathrm{Sr}$ and $\mathrm{Pb}$ isotopic compositions are interpreted as reflecting slab-derived, fluidtransported $\mathrm{Sr}$ and $\mathrm{Pb}$ from altered oceanic crust and sediment cover into the overlying mantle wedge (for example, refs 42-44). This dichotomy allows us to track slab-derived inputs through the 'subduction factory'.

The slightly higher ${ }^{206} \mathrm{~Pb} /{ }^{204} \mathrm{~Pb}$ and ${ }^{208} \mathrm{~Pb} /{ }^{204} \mathrm{~Pb}$ values from Ata and Monowai compared with other mid-Tonga-Kermadec arc lavas can be explained through mixing of local pelagic sediments (as drilled at DSDP Site 204) ${ }^{26,45}$ and altered oceanic crust (Fig. 2) ${ }^{46,47}$ with Lau Basin-Havre Trough back-arc mantle. ' $U$ ' and ' $V$ ' lavas have similar to slightly higher ${ }^{206} \mathrm{~Pb} /{ }^{204} \mathrm{~Pb}$, but significantly higher ${ }^{208} \mathrm{~Pb} /{ }^{204} \mathrm{~Pb}$ values than local sediment plus 'normal' altered oceanic crust (Fig. 3). These latitudinal variations in $\mathrm{Pb}$ isotope compositions (Fig. 3a,b) thus cannot be explained by input of pelagic sediment and/or 'normal' altered oceanic crust-derived $\mathrm{Pb}$. Similar ${ }^{207} \mathrm{~Pb} /{ }^{204} \mathrm{~Pb}$ and ${ }^{87} \mathrm{Sr} /{ }^{86} \mathrm{Sr}$ values in lavas along the mid-Tonga arc north of Ata and Kermadec arc south of Monowai argue against increased aqueous fluidtransported sediment $\mathrm{Pb}$ and $\mathrm{Sr}$ input to the central TongaKermadec arc lavas. Addition of Louisville components having higher ${ }^{206} \mathrm{~Pb} /{ }^{204} \mathrm{~Pb},{ }^{208} \mathrm{~Pb} /{ }^{204} \mathrm{~Pb}$, similar to higher ${ }^{87} \mathrm{Sr} /{ }^{86} \mathrm{Sr}$ and similar ${ }^{207} \mathrm{~Pb} /{ }^{204} \mathrm{~Pb}$ isotope composition can explain the variation in $\mathrm{Sr}$ and $\mathrm{Pb}$ isotope compositions of Monowai, ' $\mathrm{U}$ ', ' $\mathrm{V}$ ' and 'Ata'. Hence, we interpret latitudinal variations in $\mathrm{Pb}$ isotope compositions as reflecting the variable availability and incorporation of $\mathrm{Pb}$ and $\mathrm{Sr}$ derived from Louisville volcanic material into partial melts. Following previous results from Monowai ${ }^{12,32}$, the pre-Louisville $\mathrm{Pb}$ and $\mathrm{Sr}$ isotope composition of the mantle wedge most likely resembles that of the Lau Basin north of $\sim 22^{\circ} \mathrm{S}$, with $\sim 0.5 \%$ fluid-derived $\mathrm{Pb}$ and a small $\mathrm{Sr}$ contribution from the subducted sediment (cf. that drilled in the upper $100 \mathrm{~m}$ of DSDP Site 204) (for example, refs 12,32). Assuming an average Louisville isotopic composition of ${ }^{206} \mathrm{~Pb} /{ }^{204} \mathrm{~Pb}=19.34, \quad{ }^{208} \mathrm{~Pb} /{ }^{204} \mathrm{~Pb}=39.04$ and ${ }^{87} \mathrm{Sr} /{ }^{86} \mathrm{Sr}=0.70359$, up to $\sim 40 \%$ of a slab-derived Louisville signature, is required to explain the highest ${ }^{206} \mathrm{~Pb} /{ }^{204} \mathrm{~Pb},{ }^{208} \mathrm{~Pb} /$ ${ }^{204} \mathrm{~Pb}$ and ${ }^{87} \mathrm{Sr} /{ }^{86} \mathrm{Sr}$ values for 'V' (Fig. 3d,e), a $\sim 20 \%$ for ' $U$ ' and $\sim 5 \%$ for Monowai, Ata and Valu Fa (Fig. 3d,e). The more radiogenic nature of $\mathrm{Sr}$ in volcaniclastic sediments makes it possible to discriminate between sediment- and lava-driven compositional variations. Incorporation of volcaniclastic material into the mantle source beneath the central TongaKermadec arc should result in elevated $\mathrm{Sr}$ isotope values, which is only observed to a minor extent in lavas from ' $U$ ' and ' $\mathrm{V}$ '. $\mathrm{Pb}$ and $\mathrm{Sr}$ each have different mobility in aqueous fluids (for example, refs 43,44$)$ and may, therefore, be decoupled. However, as we observe only a minor increase in $\mathrm{Sr}$, we favour a predominant influence through dehydration of the altered Louisville crust. The progressive increase of $\mathrm{Ba} / \mathrm{Th}$ at similar ${ }^{206} \mathrm{~Pb} /{ }^{204} \mathrm{~Pb}^{45,37}$ suggests that the slab-derived fluids beneath the Tonga arc have high $\mathrm{Ba} / \mathrm{Th}(\sim 1,200)$ and ${ }^{206} \mathrm{~Pb} /{ }^{204} \mathrm{~Pb}$ of 18.5-18.6, which, if applied to Louisville-derived fluid, would result in similarly high to even higher $\mathrm{Ba} / \mathrm{Th}$, and ${ }^{206} \mathrm{~Pb} /{ }^{204} \mathrm{~Pb}$ of $\sim 19.0$ can be inferred (Fig. 4 ).

Elevated ${ }^{206} \mathrm{~Pb} /{ }^{204} \mathrm{~Pb}$ and ${ }^{208} \mathrm{~Pb} /{ }^{204} \mathrm{~Pb}$ values in the northernmost Tonga arc volcanoes Tafahi and Niuatoputapu have been attributed to local $\mathrm{Pb}$ input from the subducted 

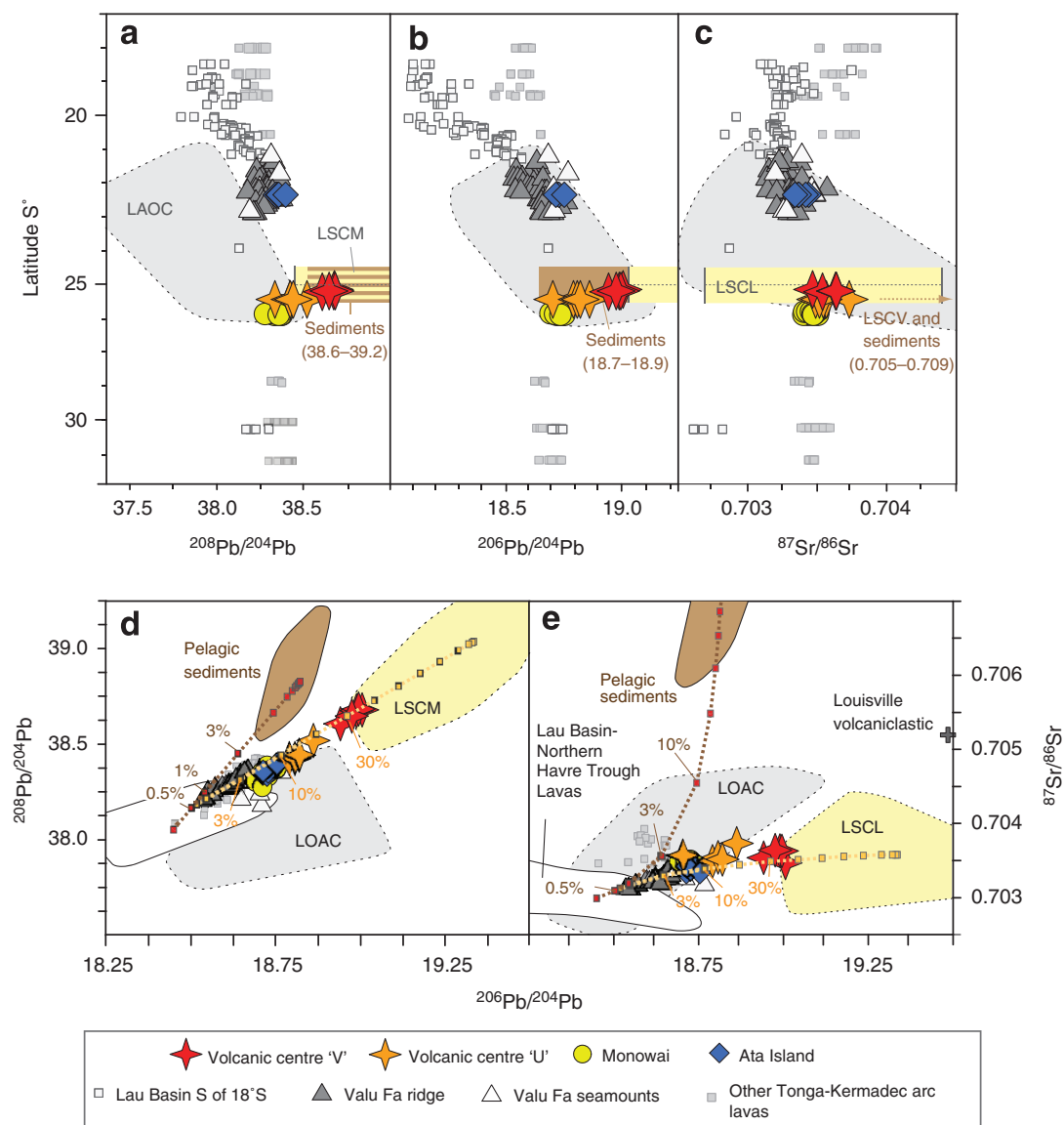

Figure 3 | Sr and $\mathbf{P b}$ isotope data. (a) Latitude ${ }^{\circ} \mathrm{S}$ versus ${ }^{208} \mathrm{~Pb} /{ }^{204} \mathrm{~Pb},(\mathbf{b}){ }^{206} \mathrm{~Pb} /{ }^{204} \mathrm{~Pb},(\mathbf{c}){ }^{87} \mathrm{Sr} /{ }^{86} \mathrm{Sr}$, (d) ${ }^{206} \mathrm{~Pb} /{ }^{204} \mathrm{~Pb}$ versus ${ }^{208} \mathrm{~Pb} /{ }^{204} \mathrm{~Pb}$ and (e) ${ }^{206} \mathrm{~Pb} /{ }^{204} \mathrm{~Pb}$ versus ${ }^{87} \mathrm{Sr} /{ }^{86} \mathrm{Sr}$. Dashed lines with squares are mixing curves between the Lau Basin-northern Havre Trough lavas, pelagic sediments (brown) and Louisville lavas (yellow). See Supplementary Table S2 for modelling details. LAOC (local altered oceanic crust) after refs 46,47. LSVC,

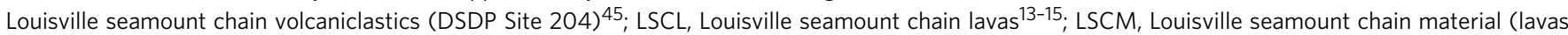
and volcaniclastics). Sediment data are taken from Ewart et al. ${ }^{45}$ Lau Basin and northern Havre Trough lavas are after refs 32,33,37,38. Valu Fa Ridge and seamount lava data are after refs 33,35-38. Other Tonga-Kermadec arc lava data are taken from refs 12,33,37,45,57,58,62. As discussed in refs 33,37,58 the $\mathrm{Pb}$ isotope data set of Turner et al. ${ }^{26}$ were affected by analytical artifacts leading to lower ${ }^{206} \mathrm{~Pb} /{ }^{204} \mathrm{~Pb}$ values outside of the analytical error compared with new analyses on the same samples and were omitted in this compilation. For further details, the reader is referred to refs $33,37,58$.

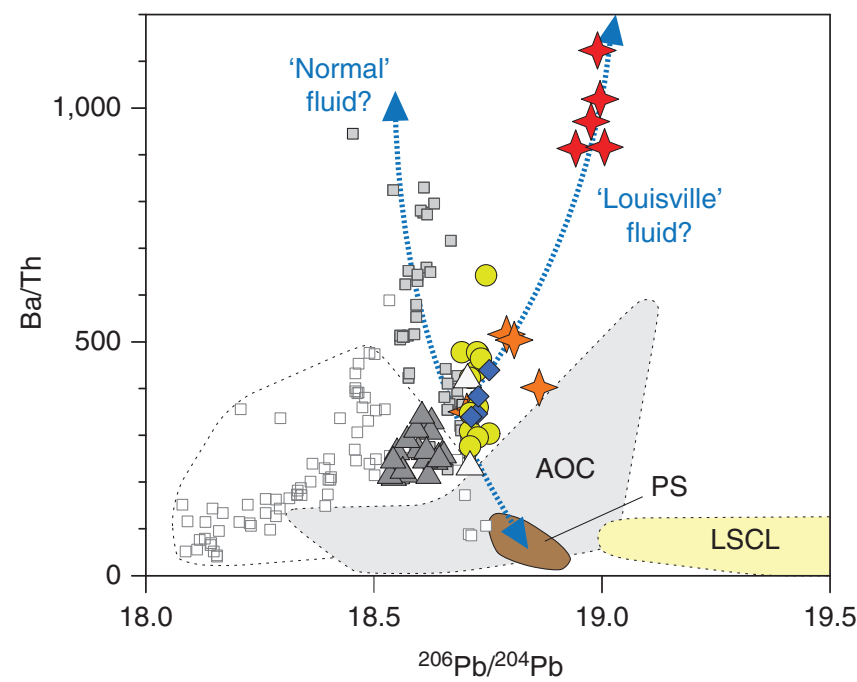

Figure 4 | Fluid composition. $\mathrm{Ba} / \mathrm{Th}$ versus ${ }^{206} \mathrm{~Pb} /{ }^{204} \mathrm{~Pb}$ modified after Turner and Hawkesworth ${ }^{63}$ to determine the $\mathrm{Pb}$ isotope composition of the slab-derived 'Louisville' fluid. See caption of Fig. 3 for data sources and acronyms. PS = Pelagic sediments.
Louisville crust and volcaniclastics (Fig. 1) (for example, refs 26,37,42). In contrast to the elevated ${ }^{206} \mathrm{~Pb} /{ }^{204} \mathrm{~Pb}$ and ${ }^{208} \mathrm{~Pb} /{ }^{204} \mathrm{~Pb}$ values in lavas from the central Tonga-Kermadec arc, those from Tafahi and Niuatoputapo are accompanied by higher ${ }^{86} \mathrm{Sr} /{ }^{87} \mathrm{Sr}$, $\mathrm{Th}, \mathrm{Nb}, \mathrm{Ta}$ and light to middle rare-earth element contents, and low ${ }^{143} \mathrm{Nd} /{ }^{144} \mathrm{Nd}$, interpreted to reflect a $\sim 1 \%$ contribution of a sediment partial melt including a signature from the Louisville volcaniclastics ${ }^{26,42}$. However, $\sim 2.5$ to $14 \mathrm{Ma}$ and $44 \mathrm{Ma}$ lavas from Lau Ridge and Eua Island, which formed along the 'proto Tonga-Kermadec' (Vitiaz) arc, also display elevated ${ }^{206} \mathrm{~Pb} /{ }^{204} \mathrm{~Pb}$, ${ }^{208} \mathrm{~Pb} /{ }^{204} \mathrm{~Pb}$ and ${ }^{87} \mathrm{Sr} /{ }^{86} \mathrm{Sr}$, but higher ${ }^{143} \mathrm{Nd} /{ }^{144} \mathrm{Nd}$ values than the Niuatoputapu and Tafahi lavas (for example, refs 37,42). The elevated Lau Ridge ${ }^{206} \mathrm{~Pb} /{ }^{204} \mathrm{~Pb}$ and ${ }^{208} \mathrm{~Pb} /{ }^{204} \mathrm{~Pb}$ isotope signatures have therefore been present since $\sim 44 \mathrm{Ma}$, suggesting that the high ${ }^{206} \mathrm{~Pb} /{ }^{204} \mathrm{~Pb}$ and ${ }^{208} \mathrm{~Pb} /{ }^{204} \mathrm{~Pb}$ isotope signatures represent a locally enriched mantle component beneath the northern Lau-Tonga Ridge system, likely introduced into the mantle beneath the northern-most Tonga arc system during the opening of the Lau Basin (for example, ref. 48). Furthermore, Todd et al. ${ }^{41}$ suggests that these ambient mantle wedge compositional heterogeneities exist beneath the entire Tonga-Kermadec arc. The more extreme geochemical composition of the Tafahi and Niuatoputapu lavas could, 
therefore, be alternatively explained through partial melting of a locally enriched mantle with ocean-island-type affinities ( \pm a sedimentary component), similar to the interpretation of Todd et al. ${ }^{41}$

The lack of a Louisville signature in the lavas north of Ata suggests that such a signature can only be detected in more recent lavas in the vicinity of the subducting Louisville seamounts. There is uncertainty about the age of Ata Island but, based on moderate ${ }^{238} \mathrm{U}$ excess in Ata lavas and the lack of recent activity, it could be a few hundred thousand years old ${ }^{26}$. Similar to lavas from the central Tonga-Kermadec arc, back-arc lavas from the southern end of the Valu Fa ridge and Valu Fa off-axis seamounts located behind Ata Island have radiogenic ${ }^{206} \mathrm{~Pb} /{ }^{204} \mathrm{~Pb}$ and ${ }^{208} \mathrm{~Pb} /{ }^{204} \mathrm{~Pb}$ values (Fig. 3a-d) and elevated ratios of elements immobile in aqueous fluids (for example, $(\mathrm{La} / \mathrm{Sm})_{N}$ ) (not shown) compared with mid-southern Lau basin lavas. The increases in ${ }^{206} \mathrm{~Pb} /{ }^{204} \mathrm{~Pb}$, ${ }^{208} \mathrm{~Pb} /{ }^{204} \mathrm{~Pb}$ and $(\mathrm{La} / \mathrm{Sm})_{N}$ strongly suggest regional-scale Louisville-related mantle source enrichment in proximity to the present intersection of the Louisville seamount chain with the Tonga-Kermadec trench.

The alternative explanation for the elevated lava ${ }^{206} \mathrm{~Pb} / 204 \mathrm{~Pb}$ and ${ }^{208} \mathrm{~Pb} /{ }^{204} \mathrm{~Pb}$ values in the central Tonga-Kermadec arc lavas is ambient mantle heterogeneity ${ }^{41}$. However, partial melting of a heterogeneous mantle wedge would not only change fluid-mobile elements, but also fluid-immobile element ratios (such as $\mathrm{La} / \mathrm{Yb} ; \mathrm{Th} / \mathrm{Yb}, \mathrm{Zr} / \mathrm{Y}$ ) and ${ }^{143} \mathrm{Nd} /{ }^{144} \mathrm{Nd}$; although observed in Ata lavas, this is not observed in the lavas from Monowai, ' $U$ ' and ' $\mathrm{V}$ '. A more westerly azimuth of the subducted Louisville seamount chain (see below), when combined with the observed isotopic anomaly in the lavas from the central TongaKermadec arc system, strongly argues for a Louisvillederived signature, although the existence of an old, inherited enriched component in the mantle wedge beneath Ata cannot be ruled out.

Location of the Louisville seamount chain beneath the arc. Regionally, the Louisville collision zone is characterized by a $3 \mathrm{~km}$ shallowing in axial trench depth, a $15^{\circ}$ anticlockwise rotation of the trench azimuth and a rough, hummocky forearc on the IndoAustralian plate.

The small-scale morphological expressions of the Louisville collision zone can be isolated from the large-amplitude, longwavelength trench-normal topographic expression of the TongaKermadec subduction zone using spectral techniques (Fig. 5). This long-wavelength signal often overwhelms and masks smaller-scale structures and when removed, residual bathymetric anomalies exceeding $\pm 2 \mathrm{~km}$ are observed within the fore-arc, arc and back-arc of the Louisville collision zone (Fig. 5). Positive bathymetric anomalies of $\sim 2 \mathrm{~km}$ immediately NW of Osbourn seamount, the oldest $(76.7 \pm 0.8 \mathrm{Ma})^{49}$ unsubducted seamount in the Louisville chain, are interpreted as the presently subducting portion of the chain. Forearc bathymetric anomalies are, however, located west of the projected track of the Louisville seamount chain, assuming a continuation of the $340^{\circ}$ azimuth observed on the seaward side of the trench. When coupled with bathymetricpositive anomalies observed along the southern portion of the Tonga Ridge and within the back-arc, a $\sim 50^{\circ}$ anticlockwise rotation in the geometry of the chain can be inferred. The elevated back-arc topography west to northwest of the contemporary collision zone has been attributed to underplating of Louisville Ridge crust ${ }^{50}$.

The suggestion that the Louisville seamount chain has a more westerly track than its younger $340^{\circ}$ azimuth is supported by another defining characteristic of the Louisville collision zone, namely, the region of seismic quiescence known as the 'Louisville

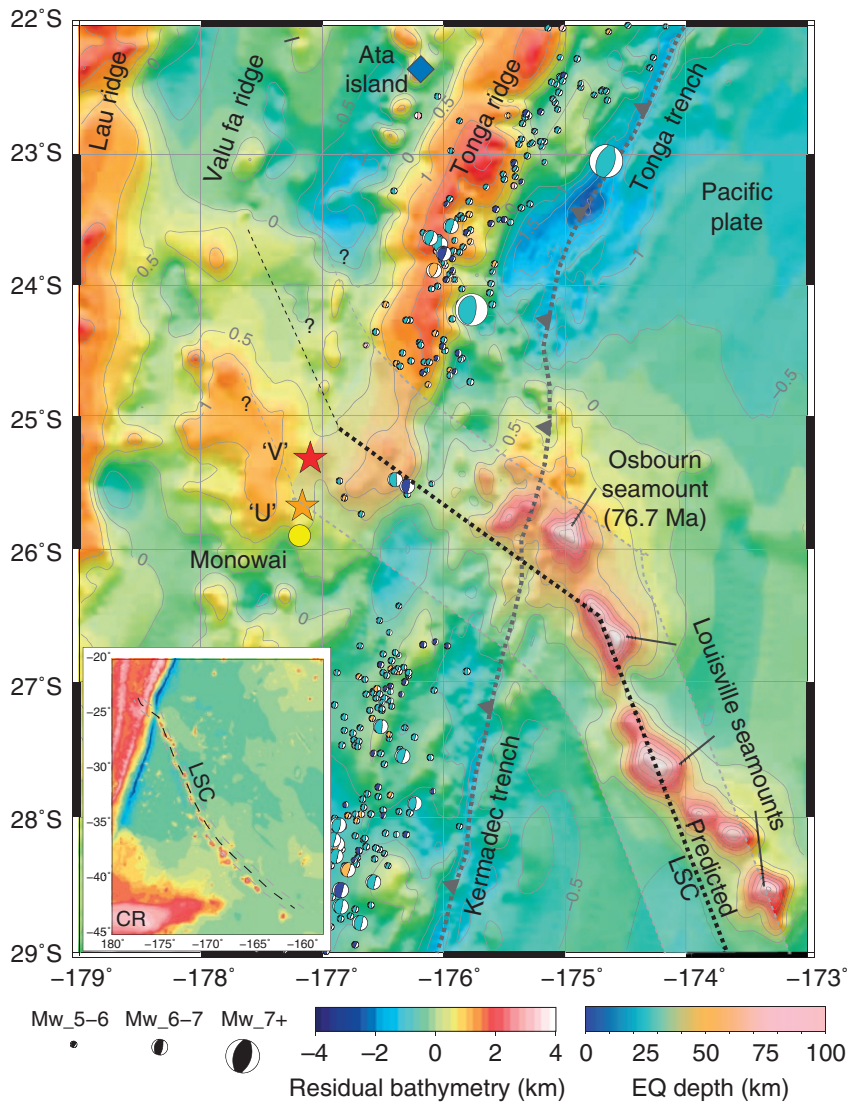

Figure 5 | Predicted Louisville hotspot track. Predicted Louisville hotspot track (black dashed line) reconstructed from absolute Pacific plate reconstruction rotations in model WK08-G by Wessel and Kroenke 52 (the location rotation point towards the westerly trend of the Louisville seamount chain south of Osbourn seamount is owing to the WKO8-G models uncertainty). Grey lines provide $95 \%$ confidence region delimiting the maximum distance from the predicted track in which seamounts generated by the Louisville hotspot are observed. Grey dashed line with westward facing teeth demarcates the trench. Focal mechanisms for magnitudes $\geq 5$ are from the Harvard CMT catalogue and are scaled according to magnitude and coloured for depth revealing the geometry of the Louisville seismic gap. CR, Chatham Rise; EQ, Earthquake; LSC, Louisville seamount chain; Mw, Earthquake Magnitude.

gap ${ }^{51}$; Fig. 5). This gap shows a $40 \%$ reduction in shallow $(0-100 \mathrm{~km})$ seismicity compared with the regions immediately to the north and south, and the geometry of the sharp boundaries that delimit the seismic gap (when rotated $40-50^{\circ}$ anticlockwise from the unsubducted Louisville seamount chain trend) supports an anticlockwise rotation in the geometry of the Louisville Ridge. The WK08-G total reconstruction rotation poles the Pacific plate of Wessel and Kroenke ${ }^{52}$ suggest an anticlockwise rotation of $\sim 35^{\circ}$ for the Louisville seamount chain of seamounts about a point just to the south of Osbourn Seamount. The contemporaneity of the Osbourn Seamount $(76.7 \pm 0.8 \mathrm{Ma})^{49}$ with the Detroit seamount $(75.8 \pm 0.6 \mathrm{Ma})^{53}$ at the northern end of the Hawaii-Emperor seamount chain suggests that the anticlockwise kink in the Louisville seamount chain is the reciprocal of the Detroit-Meiji bend along the Emperor chain (for example, ref. 16) and can also be observed in the computed plume hotspot tracks of Steinberger et al. ${ }^{54}$

An anticlockwise rotation in the subducted portion of the Louisville Ridge serves to limit the northward extent of 
paleo-ridge-collision zones and increases the age of collision between the Louisville Ridge and regions of the Tonga trench immediately north of the contemporary collision zone. Applying a $50^{\circ}$ anticlockwise rotation for the portion of the Louisville seamount chain older than the Osbourn Seamount (76.7 Ma) in the kinematic model of Ruellan et al. ${ }^{10}$ reduces the rate of southward migration of the intersection point of the seamount chain with the Tonga-Kermadec trench from $\sim 180 \mathrm{~km} \mathrm{Myr}^{-1}$ (ref. 20), to $<45 \mathrm{~km} \mathrm{Myr}^{-1}$.

\section{Discussion}

Based on U-Th and ${ }^{231} \mathrm{~Pa}^{235} \mathrm{U}$ isotope data on lavas from Tonga-Kermadec arc-front volcanoes and the southern Lau Basin, it has been inferred that the time elapsed from fluid addition from the subducting slab to eruption was between $\sim 30 \mathrm{kyr}$ and $60 \mathrm{kyr}$ (for example, refs 26,38,55). However, three studies on Tongan-Kermadec arc lavas estimated an even faster fluid addition time of $<8 \mathrm{kyr}^{56-58}$.

Subduction recycling times of $\mathrm{Pb}$ are more difficult to obtain. It has been demonstrated ${ }^{42}$ that $\mathrm{Pb}$ recycling times for slab-derived fluid addition to eruptions in the northern Tonga arc are between $0-3 \mathrm{Myr}$, with major fluid release occurring at $40-80 \mathrm{~km}$ depth during the transition from blueschist to eclogite, at temperatures of $500-600{ }^{\circ} \mathrm{C}$ (for example, refs 44,59 ). Assuming a constant convergence rate at the central Tonga-Kermadec arc of $\sim 7 \mathrm{~cm}$ per year, the Louisville signature would require $0.6-1.2 \mathrm{Myr}$ to reach the major fluid release zone at $40-80 \mathrm{~km}$ depth. In addition, assuming conservative $3 \mathrm{Myr}$ for $\mathrm{Pb}$ from fluid addition to eruption as suggested by Regelous et al. ${ }^{42}$, the signature will require $\sim 4 \mathrm{Myr}$ from initial subduction to its appearance in the erupted lavas. Based on our revised southward migration of the Louisville collision zone of $<45 \mathrm{~km} \mathrm{Myr}^{-1}$, the Louisville signature at $\sim 40-80 \mathrm{~km}$ depth would have been located $\sim 125 \mathrm{~km}$ further north than its present position $(\sim 180 \mathrm{~km}$ north of Monowai) $\sim 3 \mathrm{Myr}$ ago. This permits a maximum southward mantle flow of $\sim 6 \mathrm{~cm}$ per year for the Louisville $\mathrm{Pb}$ isotopic signature to reach the source beneath the Monowai volcanic centre. However, as $\mathrm{Pb}$ is more fluid mobile than $\mathrm{U}$ (for example, ref. 59) a significant proportion of $\mathrm{Pb}$ must have entered the melting zone within the past $50 \mathrm{kyr}$, as estimated by U-series disequilibria. Such fast recycling rates are consistent with a predominantly trench-normal mantle flow beneath the central Tonga-Kermadec arc.

Elevated ${ }^{206} \mathrm{~Pb} /{ }^{204} \mathrm{~Pb}$ and ${ }^{208} \mathrm{~Pb} /{ }^{204} \mathrm{~Pb}$ in the lavas from Monowai to Ata are consistent with a lateral spread of the mantle containing a $\sim 400 \mathrm{~km}$-wide fluid-derived Louisville seamount chain component, suggesting either a laterally expanding and slightly southward moving mantle diaper, or the accretion of a flexurally supported and buoyant Louisville crust onto the forearc crust. This may also account for the more elevated topography of the arc north of the Louisville Ridge, compared with that to the south ${ }^{10}$. In addition, based on the revised southward migration rate of $<45 \mathrm{~km} \mathrm{Myr}^{-1}$, initial subduction of the Louisville seamount chain must have occurred at least $\sim 7 \mathrm{Myr}$ ago to explain the geochemical anomaly in the lavas from Ata Island and the southern Valu Fa Ridge. Relatively stationary and continuous subduction of the Louisville chain for the past $\sim 7 \mathrm{Myr}$, and possibly the under-plating of Louisville crust beneath the oceanic Australian Plate, can both explain the effective locking and cessation of back-arc opening rates south of the southern Lau Basin. Rapid southwards mantle flow has been proposed to occur beneath the northern Tonga arc and Lau Basin where back-arc opening rates are fast. Conversely, a threefold decrease in back-arc opening combined with the subduction underplating of Louisville crust may have resulted in greatly decelerated southward or trench-normal mantle flow beneath the central Tonga-Kermadec arc.

\section{Methods}

Analytical details. For trace element analysis, $\sim 100 \mathrm{mg}$ of powdered sample was digested in a microwave vessel using $6 \mathrm{ml}$ of $28.9 \mathrm{M} \mathrm{HF}$ and $4 \mathrm{ml}$ of $15.8 \mathrm{M} \mathrm{HNO}_{3}$. A 60-min ramped heat programme was run to $220^{\circ} \mathrm{C}$ at a maximum of $40 \mathrm{bar}$. After completing the heating programme, the vessels were cooled to room temperature and carefully vented in a fume hood. After confirming complete sample digestion by visual inspection, evaporation was performed in two steps. The contents of each microwave vessel were quantitatively transferred to a Savillex digestion vessel, transferred to a $70^{\circ} \mathrm{C}$ hotplate, and dried to incipient dryness to evaporate most of the $\mathrm{HF}$ and prevent fluoride formation. These vessels were allowed to cool, then $2 \mathrm{ml}$ of $12.1 \mathrm{M} \mathrm{HCl}$ was added to each, which were then capped and heated to $150^{\circ} \mathrm{C}$ on a hotplate for $24 \mathrm{~h}$. The vessels were then allowed to cool, were uncapped and returned to a $70^{\circ} \mathrm{C}$ hotplate to evaporate to incipient dryness. Finally, the residue was dissolved in $10 \mathrm{ml}$ of $2 \mathrm{wt} . \%$ $\mathrm{HNO}_{3}$ containing 1 p.p.b. In (internal standard) and made up to a final volume of $50 \mathrm{ml}$. Clear solutions were obtained in all cases and procedural blank solutions were also prepared. The solutions were analysed at the Queen's Facility for Isotope Research, Kingston, Ontario, using an Element XR, HighResolution inductively coupled plasma mass spectrometry (ICP-MS). Standard analyses are given in Supplementary Table S1.

Isotope analysis. For chemical analysis, fresh cores of the samples were extracted, repeatedly washed in deionised water (in an ultrasonic bath) to remove sea salt, then crushed, handpicked and reduced to powder in an agate mill. Isotope analyses were undertaken at the University of Melbourne. Between 50 and $100 \mathrm{mg}$ of fresh, clean chips, $1-5 \mathrm{~mm}$ in diameter, were handpicked for isotopic analysis and then leached in hot $6 \mathrm{~N} \mathrm{HCl}$ for $30 \mathrm{~min}$ to remove any contaminants. Samples were then washed in ultrapure water and dissolved in $\mathrm{HF} / \mathrm{HNO}_{3}$. Separation of $\mathrm{Pb}, \mathrm{Sr}$ and $\mathrm{Nd}$ involved standard ion exchange procedures using Eichrom ion-specific resins. Analytical blanks are in all cases insignificant relative to the amount of sample processed and no blank corrections were made. Separated $\mathrm{Sr}, \mathrm{Nd}$ and $\mathrm{Pb}$ were run on a $\mathrm{Nu}$ Instruments $\mathrm{MC}$-ICP-MS using methods documented previously in Woodhead ${ }^{60}$ for $\mathrm{Pb}$ and Hergt et al. ${ }^{61}$ for $\mathrm{Sr}$ and $\mathrm{Nd}$. ${ }^{87} \mathrm{Sr} /{ }^{86} \mathrm{Sr}$ was normalized to ${ }^{86} \mathrm{Sr} /{ }^{88} \mathrm{Sr}=0.1194$ and reported relative to NIST SRM $987=0.710250$. Internal precision is typically $<0.000015$ ( 2 s.e.) with reproducibility ( 2 s.d. of repeat runs) $\leq \pm 0.000040 .{ }^{143} \mathrm{Nd} /{ }^{144} \mathrm{Nd}$ was normalized to ${ }^{146} \mathrm{Nd} /{ }^{145} \mathrm{Nd}=2.0719425$ (equivalent to ${ }^{146} \mathrm{Nd} /{ }^{144} \mathrm{Nd}=0.7219$ ) and reported relative to La Jolla $\mathrm{Nd}=0.511865$. Internal precision is typically $<0.000010$ (2 s.e.) with reproducibility ( 2 s.d. of repeat runs) $\leq \pm 0.000020$. Pb isotope ratios are reported relative to SRM 981 values of $16.935,15.489$ and 36.701 with reproducibility ( 2 s.d. of repeat runs) $\leq \pm 0.03 \%$.

\section{References}

1. Pearce, J. A. \& Peate, D. W. Tectonic implications of the composition of volcanic arc magmas. Ann. Rev. Earth Planet. Sci. 23, 251-285 (1995).

2. Elliott, T., Plank, T., Zindler, A., White, W. \& Bourdon, B. Element transport from slab to volcanic front at the Mariana arc. J. Geophys. Res. 102, 14991-15019 (1997).

3. Stern, R. J. Subduction zones. Rev. Geophys. 40, 1012 (2002).

4. Long, M. D. \& van der Hilst, R. D. Upper mantle anisotropy beneath Japan from shear wave splitting. Phys. Earth Planet. Interior 151, 206-222 (2005).

5. Hoernle, K. A. et al. Arc-parallel flow in the mantle wedge beneath Costa Rica and Nicaragua. Nature 451, 1094-1098 (2008).

6. Heyworth, Z., Knesel., K. M., Turner, S. P. \& Arculus, R. J. Pb-isotopic evidence for rapid trench-parallel mantle flow beneath Vanuatu. J. Geological Soc. Lond. 168, 265-271 (2011).

7. Smith, G. D. et al. A complex pattern of mantle flow in the Lau Basin. Science 292, 713-716 (2001).

8. Conder, J. A. \& Wiens, D. A. Rapid mantle flow beneath the Tonga volcanic arc. Earth Planet. Sci. Lett. 264, 299-307 (2007).

9. Turner, S. P. \& Hawkesworth, C. J. Using geochemistry to map mantle flow beneath the Lau Basin. Geology 26, 1019-1022 (1998).

10. Ruellan, E., Delteil, J., Wright, I. \& Matsumoto, T. From rifting to active spreading in the Lau Basin - Havre Trough backarc system (SW Pacific): locking/unlocking induced by seamount chain subduction. Geochem. Geophys. Geosyst. 4, 8909 (2003).

11. Ewart, A. \& Hawkesworth, C. The Pleistocene-Recent Tonga-Kermadec arc lavas: interpretation of new isotopic and rare earth data in terms of depleted mantle source model. J. Petrol. 28, 495-530 (1987).

12. Timm, C., Graham, I. J., de Ronde, C. E. J., Leybourne, M. I. \& Woodhead, J. Geochemical evolution of Monowai volcanic center: new insights into the northern Kermadec arc subduction system, SW Pacific. Geochem. Geophys. Geosyst. 12, Q0AF01 (2011). 
13. Cheng, Q. et al. Isotopic Evidence for a Hotspot Origin of the Louisville Seamount Chain, Seamounts, Islands, and Atolls Vol. 43, 283-296 (American Geophysical Union, Washington, DC, USA, 1987).

14. Vanderkluysen, L. Chemical and Isotopic Studies of Deccan Traps Dikes (India) and Louisville Seamounts (South Pacific): Aspects of the Youth and Maturity of Hot Spots. PhD Thesis, SOEST/University of Hawaii (2008).

15. Beier, C., Vanderkluysen, L., Regelous, M., Mahoney, J. J. \& GarbeSchoenberg, D. Lithospheric control on geochemical composition along the Louisville Seamount Chain. Geochem. Geophys. Geosyst. 12, Q0AM01 (2011).

16. Ballance, P. F. et al. Subduction of a Late Cretaceous seamount of the Louisville Ridge at the Tonga trench: a model of normal and accelerated tectonic erosion. Tectonics 8, 953-962 (1989).

17. DeMets, C., Gordon, R. G., Argus, D. F. \& Stein, S. Effect of recent revisions to the geomagnetic reversal time scale and estimates of current plate motions. Geophys. Res. Lett. 21, 2191-2194 (1994).

18. de Ronde, C. E. J. et al. Submarine hydrothermal activity along the midKermadec Arc, New Zealand: large-scale effects on venting. Geochem. Geophys. Geosyst. 8, Q07007 (2007).

19. Watts, A. B., Duncan, R. A. \& Larson, R. L. The origin of the Louisville Ridge and its relationship to the Eltanin Fracture Zone system. J. Geophys. Res. 93, 3051-3077 (1988).

20. Lonsdale, P. A multibeam reconnaissance of the Tonga trench axis and its intersection with the Louisville guyot chain. Mar. Geophys. Res. 8, 295-327 (1986).

21. Giardini, D. \& Woodhouse, J. H. Deep seismicity and modes of deformation in Tonga subduction zone. Nature 307, 505-509 (1984).

22. Van der Hilst, R. Complex morphology of subducted lithosphere beneath the Tonga trench. Nature 374, 154-157 (1995).

23. Billen, M. I. \& Stock, J. Morphology and origin of the Osbourn Trough. J. Geophys. Res. 105, 13481-13489 (2000).

24. Sutherland, R. \& Hollis, C. Cretaceous demise of the Moa plate and strike-slip motion at the Gondwana margin. Geology 29, 279-282 (2001).

25. Clift, P. D. et al. Tracing the evolving flux from the subducting plate in the Tonga-Kermadec arc system using boron in volcanic glass. Geochim. Cosmochim. Acta 65, 3347-3364 (2001).

26. Turner, S. P. et al. Uranium-238/ thorium-230 disequilibria, magma petrogenesis, and flux rates beneath the depleted Tonga-Kermadec island arc. Geochim. Cosmochim. Acta 61, 4855-4884 (1997)

27. Graham, I. J. et al. Structure and petrology of newly discovered volcanic centers in the northern Kermadec-southern Tofua arc, South Pacific Ocean. J. Geophys. Res. B 113, 1-24 (2008).

28. Isacks, B. L. \& Barazangi, M. Island Arcs Deep Sea Trenches and Back-Arc Basins. Maurice Ewing Ser. Vol. 1 (eds Taiwani, M. \& Pitman, III W. C.) 99-114 (AGU, Washington DC, 1977).

29. de Ronde, C. E. J. et al. NZAPLUME III cruise "Northern-Kermadec Arc". Cruise Report, (2004) 75.

30. Le Maitre, R. W. et al. Igneous Rocks: A Classification and Glossary of Terms, Recommendations of the International Union of Geological Sciences, Subcommission of the Systematics of Igneous Rocks (Cambridge University Press, 2002).

31. Sun, S. S. \& McDonough, W. F. Magmatism in the Ocean Basins. Geological Society of London. (eds Saunder, A. D. \& Norry, M. J.) 313-345, (1989).

32. Haase, K. M., Worthington, T. J., Stoffers, P., Garbe-Schoenberg, D. \& Wright, I. Mantle dynamics, element recycling, and magma genesis beneath the Kermadec Arc-Havre Trough. Geochem. Geophys. Geosyst. 3, 1071 (2002).

33. Escrig, S., Bezos, A., Goldstein, S. L., Langmuir, C. H. \& Michael, P. J. Mantle source variations beneath the Eastern Lau Spreading Ceneter and the nature of subduction components in the Lau Basin-Tonga arc system. Geochem. Geophys. Geosyst. 10, Q04014 (2009).

34. Meyzen, C. M. et al. Isotopic portrayal of the Earth's upper mantle flow field. Nature 447, 1069-1074 (2007)

35. Fretzdorff, S. et al. Hydrothermal activity and magma genesis along a progatating back-arc basin: Valu Fa Ridge (southern Lau Basin). J. Geophys. Res. 111, B08205 (2006)

36. Haase, K. M., Fretzdorff, S., Muehe, R., Garbe-Schoenberg, D. \& Stoffers, P. A geochemical study of off-axis seamount lavas at the Valu Fa Ridge: constraints on magma genesis and slab contributions in the southern Tonga subduction zone. Lithos 112, 137-148 (2009).

37. Hergt, J. M. \& Woodhead, J. D. A critical evaluation of recent models for Lau-Tonga arc-backarc basin magmatic evolution. Chem. Geol. 245, 9-44 (2007).

38. Peate, D. W. U-series isotope data on Lau Basin glasses: the role of subduction -related fluids during melt generation in back-arc basins. J. Petrol. 42, 1449-1470 (2001).
39. McDonough, W. F. \& Sun, S.-s. Composition of the earth. Chem. Geol. 120, 223-253 (1995).

40. Todd, E. et al. Hf isotopic evidence for small-scale heterogeneity in the mode of mantle wedge enrichment: Southern Havre Trough and South Fiji Basin back arcs. Geochem. Geophys. Geosyst. 12, Q09011 (2011).

41. Todd, E., Gill, J. B. \& Pearce, J. A. A variably enriched mantle wedge and contrasting melt types during arc stages following subduction initiation in Fiji and Tonga, southwest Pacific. Earth Planet. Sci. Lett. 335-336, 180-194 (2012).

42. Regelous, M., Gamble, J. A. \& Turner, S. P. Mechanism and timing of $\mathrm{Pb}$ transport from subducted oceanic crust and sediment to the mantle source of arc lavas. Chem. Geol. 273, 46-54 (2010).

43. Brenan, J. M., Shaw, H. F., Ryerson, F. J. \& Phinney, D. L. Mineral-aqueous fluid partitioning of trace elements at $900^{\circ} \mathrm{C}$ and $2.0 \mathrm{GPa}$ : constraints on trace element chemistry of mantle and deep crustal fluids. Geochim. Cosmochim. Acta 59, 3331-3350 (1995).

44. Kessel, R., Schmidt, M. W., Ulmer, P. \& Pettke, T. Trace element signature of subduction-zone fluids, melts and supercritical liquids at $120-180 \mathrm{~km}$ depth. Nature 437, 724-727 (2005).

45. Ewart, A., Collerson, K. D., Regelous, M., Wendt, J. I. \& Niu, Y. Geochemical evolution within the Tonga-Kermadec-Lau arc-back-arc systems; the role of varying mantle wedge composition in space and time. J. Petrol. 39, 331-368 (1998).

46. Castillo, P. R., Lonsdale, P. F., Moran, C. L. \& Hawkins, J. W. Geochemistry of mid-Cretaceous Pacific crust being subducted along the Tonga-Kermadec Trench: Implications for the generation of arc lavas. Lithos 112, 87-102 (2009).

47. Worthington, T. J., Hekinian, R., Stoffers, P., Kuhn, T. \& Hauff, F. Osbourn Trough: structure, geochemistry and implications of a mid-Cretaceous paleospreading ridge in the South Pacific. Earth Planet. Sci. Lett. 245, 685-701 (2006).

48. Pearce, J. A., Kempton, P. D. \& Gill, J. B. Hf-Nd evidence for the origin and distribution of mantle domains in the SW Pacific. Earth Planet. Sci. Lett. 260, 98-114 (2007).

49. Koppers, A. A. P., Duncan, R. A. \& Steinberger, B. Implications of a nonlinear ${ }^{40} \mathrm{Ar} /{ }^{39} \mathrm{Ar}$ age progression along the Louisville seamount trail for models of fixed and moving hot spots. Geochem. Geophys. Geosyst. 5, Q06L02 (2004)

50. Dupont, J. \& Herzer, R. Geology and Offshore Resources of Pacific Island Arcs - Tonga Region, Circum Pacific Council for Energy and Mineral Resources Earth Science Series Vol. 2 (eds and compiler Scholl, D. W. \& Vallier, T. L.) 323-332 (Circum Pacific Council for Energy and Mineral Resources, Houston, TX, 1985).

51. Scholz, C. H. \& Small, C. The effect of seamount subduction on seismic coupling. Geology 25, 487-490 (1997).

52. Wessel, P. \& Kroenke, L. W. Pacific absolute plate motion since 145Ma: an assessment of the fixed hot spot hypothesis. J. Geophys. Res. 113, B06101, 1-21 (2008).

53. Duncan, R. A. \& Keller, R. A. Radiometric ages for basement rocks from the Emperor Seamounts ODP Leg 197. Geochem. Geophys. Geosyst. 5, Q08L03 (2004).

54. Steinberger, B., Sutherland, R. \& O'Connell, R. J. Prediction of Emperor-Hawaii seamount locations from a revised model of global plate motion and mantle flow. Nature 430, 167-173 (2004).

55. Bourdon, B., Turner, S. \& Allegre, C. Melting dynamics beneath the TongaKermadec island arc inferred from $231 \mathrm{~Pa}-235 \mathrm{U}$ systematics. Science 286, 2491-2492 (1999).

56. Turner, S., Bourdon, B., Hawkesworth, C. \& Evans, P. ${ }^{226}$ Ra- $-{ }^{230}$ Th evidence for multiple dehydration events, rapid malt ascend and the time scales of differentiation beneath the Tonga-Kermadec island arc. Earth Planet. Sci. Lett. 179, 581-593 (2000)

57. Caulfield, J. T., Turner, S. P., Smith, I. E. M., Cooper, L. B. \& Jenner, G. A. Magma evolution in the primitive, intra-oceanic Tonga arc: petrogenesis of basaltic andesites at Tofua volcano. J. Petrol. 53, 1197-1230 (2012).

58. Turner, S. et al. Magma evolution in the Primitive, Intra-oceanic Tonga Arc: rapid petrogenesis of Dacites at Fonualei volcano. J. Petrol. 53, 1231-1253 (2012).

59. Kelley, K. A., Plank, T., Farr, L., Ludden, J. \& Staudigel, H. Subduction cycling of U, Th, and Pb. Earth Planet. Sci. Lett. 234, 369-383 (2005).

60. Woodhead, J. D. A simple method for obtaining highly accurate $\mathrm{Pb}$-isotope data by MC-ICPMS. J. Anal. Atomic Spectrom. 17, 1381-1385 (2002).

61. Hergt, J., Woodhead, J. \& Schofield, A. A-type magmatism in the Western Lachlan Fold Belt? A study of granites and rhyolites from the Grampians region, Western Victoria. Lithos 97, 122-139 (2007).

62. Gamble, J., Woodhead, J., Wright, I. \& Smith, I. Basalt and sediment geochemistry and magma petrogenesis in a transect from oceanic island arc to 
rifted continental margin arc: the Kermadec-Hikurangi Margin, SW Pacific. J. Petrol. 37, 1523-1546 (1996).

63. Turner, S. \& Hawkesworth, C. J. Constraints on flux rates and mantle dynamics beneath island arcs from Tonga-Kermadec lava geochemistry. Nature 389, 568-573 (1997).

\section{Acknowledgements}

The captain and crew of RV Tangaroa are thanked for their support and skill during the NZAPLUME III expedition in 2004. We wish to thank Roland Maas for laboratory assistance at Melbourne University. Discussions with E. Todd, R.J.

Wysoczanski, F. Caratori-Tontini, R. Sutherland, K. Hoernle and M.R. Handler helped to develop ideas in this paper. This research has been supported by the Foundation of Research and Technology (New Zealand) contract C05X0406 and GNS Science core funding.

\section{Author contributions}

C.T. developed the idea and wrote the manuscript. D.B. performed plate reconstructions. D.L-M. provided trace element analyses and J.W. contributed the $\mathrm{Sr}, \mathrm{Nd}$ and $\mathrm{Pb}$ isotope analyses. C.E.J.d.R, I.J.G., M.I.L. and A.B.W. contributed to the writing of the manuscript.

\section{Additional information}

Supplementary Information accompanies this paper at http://www.nature.com/ naturecommunications

Competing financial interests: The authors declare no competing financial interests.

Reprints and permission information is available online at http://npg.nature.com/ reprintsandpermissions/

How to cite this article: Timm, C. et al. Louisville seamount subduction and its implication on mantle flow beneath the central Tonga-Kermadec arc. Nat. Commun. 4:1720 doi: 10.1038/ncomms2702 (2013). 


\section{Erratum: Louisville seamount subduction and its implication on mantle flow beneath the central Tonga-Kermadec arc}

Christian Timm, Daniel Bassett, lan J. Graham, Matthew I. Leybourne, Cornel E.J. de Ronde, Jon Woodhead, Daniel Layton-Matthews \& Anthony B. Watts

Nature Communications 4:1720 doi: 10.1038/ncomms2702 (2013); Published 16 Apr 2013; Updated 8 Jan 2014

Table 1 was inadvertently omitted during the production of this Article, and should have been referred to in the fourth paragraph of the 'Geological and geochemical background' section of the Results, as follows: ' $\mathrm{Sr}$ and $\mathrm{Pb}$ isotopic compositions of lavas from ' $U$ ', 'V', Monowai and Ata are generally more radiogenic than Pacific and Indian MORB (Table 1, Fig. 3) ${ }^{12,32,33}$, but their Nd isotopic compositions fall within the MORB range ${ }^{34}$. Table 1 appears below.

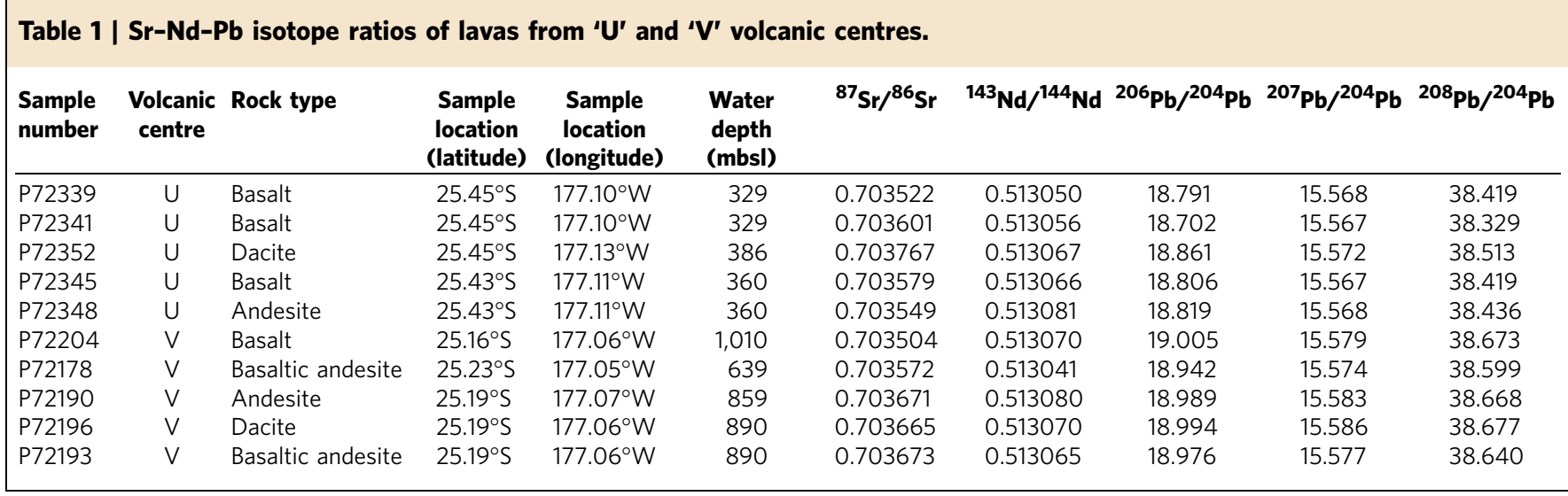

